\title{
APLIKASI PENJUALAN ONLINE KERAJINAN LOKAL KHAS MASYARAKAT NUSA TENGGARA TIMUR BERBASIS ANDROID
}

\author{
Theresia Yunita F. M. Lamawuran ${ }^{1 *}$, Paskalis A. Nani ${ }^{1}$, Frengky Tedy ${ }^{1}$ \\ ${ }^{1}$ Ilmu Komputer, Universitas Katolik Widya Mandira \\ email: "tesalamawuran06@gmail.com
}

\begin{abstract}
East Nusa Tenggara, especially Oemasi village has rich natural potential so that the people of Oemasi village can produce various kinds of high-quality local crafts and have high selling points. The craft that is produced is usually in the form of woven cloth, scarf, ukulele, and others. The problem experienced by the Oemasi village community in selling crafts is the limited promotional media with conventional methods and the method of selling local crafts via social media also has shortcomings that are stock items that still have to be updated manually and sales history that is still recorded manually. This research aims to engineer the application of local craft sales in East Nusa Tenggara based on android which can be used as an alternative to assist the people of Oemasi village in selling local crafts in East Nusa Tenggara so that sales problems with conventional methods or through social media can be resolved. The software development model used in this research is the Waterfall model.
\end{abstract}

Keywords: android; East Nusa Tenggara; local craft

Abstrak: Nusa Tenggara Timur khususnya desa Oemasi memiliki potensi alam yang kaya sehingga masyarakat desa Oemasi dapat menghasilkan berbagai macam kerajinan lokal yang sangat berkualitas dan memiliki nilai jual yang tinggi. Kerajinan yang dihasilkan biasanya berupa kain tenun, selendang, ukulele dan lain-lain. Permasalahan yang dialami masyarakat desa Oemasi dalam menjual kerajinan adalah terbatasnya media promosi dengan metode konvensional dan metode penjualan kerajinan lokal via media sosial juga memiliki kekurangan yaitu stok barang yang masih harus diupdate secara manual dan history penjualan yang masih dicatat secara manual. Penelitian ini bertujuan untuk merekayasa aplikasi penjualan kerajinan masyarakat NTT berbasis android yang dapat dijadikan sebagai alternatif untuk membantu masyarakat desa Oemasi dalam melakukan penjualan kerajinan lokal masyarakat NTT sehingga permasalahan penjualan dengan metode konvensional atau melalui media sosial dapat diatasi. Model pengembangan perangkat lunak yang digunakan dalam penelitian ini adalah model Waterfall.

Kata kunci: android, kerajinan lokal; Nusa Tenggara Timur 
DOI: https://doi.org/10.33330/jurteksi.v7i2.643

Available online at http://jurnal.stmikroyal.ac.id/index.php/jurteksi

\section{PENDAHULUAN}

Nusa Tenggara Timur ( NTT ) merupakan provinsi yang kaya akan potensi alam sehingga masyarakat NTT dapat menghasilkan berbagai macam kerajinan lokal dari hasil alam yang sangat berkualitas dan memiliki nilai jual yang tinggi. Kerajinan lokal yang dihasilkan masyarakat NTT sangat beragam dan memiliki ciri khasnya masing-masing, contohnya seperti kain tenun, replika sasando, tas tenun, anyaman, kerajinan kayu cendana, sarung dan lain sebagainya. Kerajinan ini biasanya diproduksi oleh pengrajin Usaha Kecil Menengah (UKM) yang proses produksinya masih bersifat tradisional dan hanya memanfaatkan dari hasil alam yang ada. Salah satu desa yang memproduksi kerajinan lokal ialah Desa Oemasi yang terletak di kecamatan Nekamese, kabupaten Kupang, provinsi NTT.

Desa Oemasi memiliki jumlah penduduk sebanyak 990 jiwa dengan jumlah penduduk perempuan sebanyak 481 jiwa dan jumlah penduduk laki-laki sebanyak 509 jiwa. Hasil kerajinan lokal yang menjadi ciri khas dari desa Oemasi adalah bertenun. Kegiatan bertenun di desa ini tersebar di 5 dusun dengan dominan kerajinan lokal yang dihasilkan adalah selempang kecil. Untuk kain sarung dan selimut biasa dibuat berdasarkan kebutuhan dan pemesanan baik secara langsung atau via media sosial yaitu $f a$ cebook. Para pengrajin ini ada juga yang mendapatkan alat tenun dan modal yang didanai oleh Badan Usaha Milik Desa (BUMDes) sehingga hasil tenunan tidak hanya dijual sendiri atau secara langsung oleh pengrajin, namun ada juga hasil tenun yang diserahkan pada BUMDes dan BUMDes-lah yang akan melakukan penjualan dan promosi langsung kepada tamu atau pengunjung yang datang ke kantor desa atau melalui facebook.

Untuk metode penjualan secara secara langsung ataupun melalui media sosial seperti facebook masih memiliki kekurangan masing-masing. Kekurangan dari metode penjualan secara secara langsung adalah terbatasnya media promosi sehingga pengrajin hanya membuat tenunan apabila ada yang memesan secara langsung. Kekurangan dari metode penjualan via media sosial adalah informasi mengenai stok barang yang masih harus diupdate secara manual oleh admin sehingga informasi stok belum tentu valid dikarenakan oleh kesalahan manusia (Human Error), selanjutnya menyangkut histori pembelian yang harus dicatat secara manual melalui kolom komentar atau inbox di media sosial yang mengakibatkan pihak pengelola kerajinan mengalami kesulitan dalam memanajemen informasi keuangan.

Dengan menggunakan sistem penjualan online atau disebut dengan $e$ commerce, proses penjualan dan promosi dapat dilakukan dengan lebih efisien karena semua orang dapat mengakses informasi mengenai kerajinan dengan mudah melalui gadget mereka masingmasing, informasi mengenai kerajinan yang diberikan pun [1]-[3] dapat dipastikan sangat informatif dan akurat karena proses pencatatan histori mengenai stok kerajinan dan histori pembelian pun dicatat dengan baik. Aplikasi e-commerce yang direkayasa pun berbasis mobile:apps android dikarenakan platform android sendiri sedang mengalami pertumbuhan pengguna, terlebih diwilayah Nusa Tenggara Timur [4], dan juga sistem berbasis mobile:apps sendiri memiliki beberapa keunggulan dibandingkan sistem berbasis mobile:web dari segi kecepatan, keamanan, dan juga lebih praktis dalam pengoperasiaanya [5], [6]. 
Berdasarkan kondisi yang ada maka perlu direkayasa sebuah Aplikasi Penjualan Online Kerajinan Lokal Khas Masyarakat Nusa Tenggara Timur (NTT) Studi Kasus Desa Oemasi. Aplikasi ini dibuat dengan menggunakan android, sehingga dapat dijadikan sebagai alternatif untuk membantu masyarakat desa Oemasi dalam melakukan penjualan kerajinan lokal Masyarakat NTT.

Tujuan dari penelitian ini adalah untuk mendukung proses monitoring barang agar dapat terkontrol dengan lebih baik lagi sehingga dapat menjadi acuan sebagai pengambil keputusan dengan cepat [7].

Penelitian lainnya adalah penelitian yang menghasilkan sebuah analisa dan perancangan e-marketing bagi UMKM pengrajin Tas di Desa Gulang [8], Aplikasi E-Commerce Penjualan Souvenir Pernikahan Pada Toko 'Xyz' [9], dan Perancangan Sistem Informasi Akademik Berbasis Web Pada Sd Islam Luqmanul Hakim Bekasi [10], dimana semua produk yang dihasilkan dalam penelitian ini bertujuan untuk mempercepat proses penyebaran informasi dengan cepat dan akurat, sehingga jangkauan pemasaran produk menjadi lebih luas, mempermudah proses transaksi dengan adanya transaksi secara online, dan juga dapat mempermudah pemilik produk dalam merekap Kembali seluruh transaksi yang pernah dilakukan.

\section{METODE}

Penelitian ini dilakukan di desa Oemasi kecamatan Nekamese kabupaten Kupang. Model yang diinginkan dalam mengembangkan perangkat lunak pada penelitian ini adalah model waterfall [11]. Berikut adalah tahapan-tahapan pengembangan perangkat lunak menggunakan model waterfall.

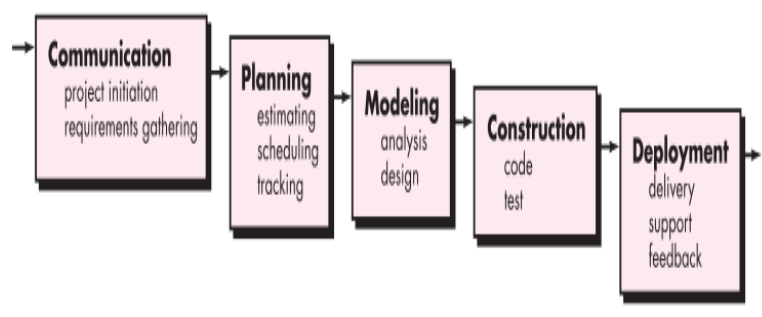

Gambar 1. Bagan Model Waterfall

\section{Communication}

Fase pertama yaitu melakukan komunikasi dengan masyarakat NTT yang membuat kerajinan-kerajinan khas NTT mengenai kendala - kendala yang mereka hadapi dalam memasarkan hasil kerajinan mereka. Komunikasi juga dilakukan dengan para target atau calon pembeli tentang permintaan atau kesulitan yang mereka dapati saat ingin membeli kerajinan khas NTT. Informasi tambahan mengenai perancangan dan pembangunan aplikasi informasi didapat memalui buku, internet, dan jurnal-jurnal penelitian.

2. Planning

Setelah menganalisa permasalahan yang dihadapi oleh pengrajin tenun di desa Oemasi dan calon pembeli, tahap berikut adalah melakukan Perencanaan. Pada fase ini hal-hal yang dilakukan adalah memperkirakan durasi pengerjaan software, risiko yang terjadi, sumbersumber yang dilakukan, hasil yang akan dibuat, dan juga membuat jadwal pengerjaan software.

3. Modeling

Setelah menganalisa permasalahan dari pihak penjual dan pembeli, langkah selanjutnya adalah mendesain sistem. Desain Sistem membantu dalam menentukan perangkat keras (hardware) dan sistem yang diperlukan dan juga mem- 
bantu dalam mendefinisikan arsitektur sistem secara keseluruhan.

4. Construction

Pada Fase ini segala perancangan kemudian dikonstruksi menggunakan pengkodean menggunakan Bahasa yang dapat dikenal oleh komputer. Setelah melakukan pengkodean langkah berikutnya adalah melakukan testing, hal ini diperlukan untuk menemukan kesalahankesalahan yang terdapat dalam sistem yang telah direkayasa. Pada tahap ini, pengkodean direkayasa menggunakan Java sedangkann tools atau alat yang digunakan ialah Android Studio v3.2.1 dan untuk merancang basis data menggunakan MySQL.

5. Deployment

Pada Fase ini software kemudian diberiakan kepada pelanggan, dievaluasi, dipelihara, dan dikembangkan secara berkala bersarkan Feedback yang diberikan oleh user ataupun costumer sehingga software dapat berjalan dan berkembang sesuai dengan fungsinya.

\section{HASIL DAN PEMBAHASAN}

\section{Analisis Sistem}

Setelah melakukan komunikasi dengan pengrajin dan pihak pemerintah desa Oemasi, maka dibuatlah spesifikasi untuk sistem yang akan direkayasa sebagai berikut :

1. Sistem yang dirancang dapat mengolah data (menginput, menampilkan, mengedit dan menghapus) yang berkaitan dengan penjualan kerajinan.

2. Output dari sistem ini berupa grafik penjualan kerajinan, laporan kerajinan, laporan penjualan setiap kerajinan dan laporan penjualan kerajinan berdasarkan pengrajin.

3. Terdapat 3 pengguna dalam sistem ini yaitu admin, penjual kerajinan dan pembeli.

4. Aplikasi yang direkayasa untuk pelanggan adalah berbasis android dan aplikasi yang direkayasa untuk admin adalah berbasis android dan website.

\section{Diagram Konteks}

Setelah melakukan analisa dan menentukan spesifikasi untuk sistem yang direkayasa maka dibuatlah diagram konteks. Diagram konteks adalah diagram yang menyajikan tinjauan umum sistem dan interaksinya dengan seluruh pengguna diluar system [12].

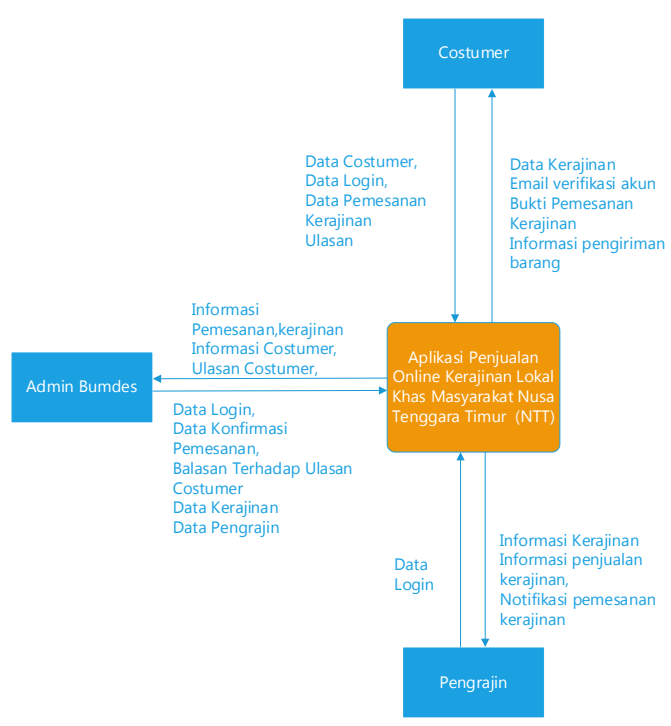

Gambar 2. Diagram Konteks

\section{Implementasi}

1. Halaman Login dan Registrasi

Halaman login digunakan oleh pelanggan untuk melakukan otentikasi sebelum menggunakan sistem. Otentikasi yang dilakukan adalah dengan menggunakan email dan password. Apabila pelanggan tidak memiliki akun, maka pelanggan 
Available online at http://jurnal.stmikroyal.ac.id/index.php/jurteksi

dapat melakukan registrasi pada halaman register.
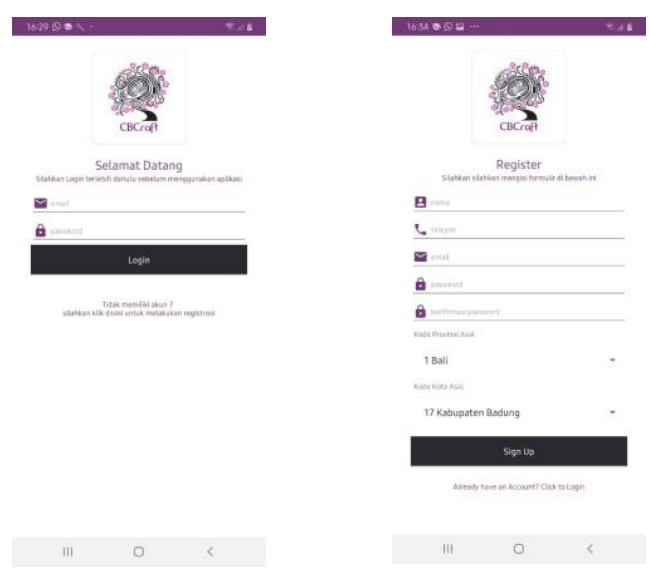

Gambar 4. Halaman Login dan Registrasi

2. Halaman Detail Kerajinan
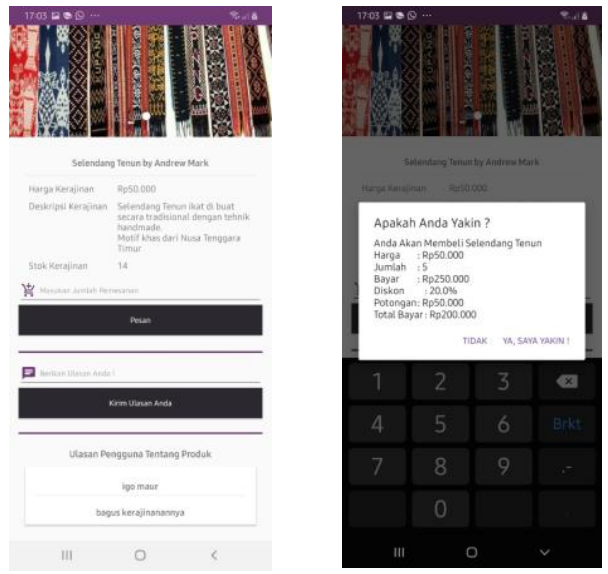

Gambar 5. Halaman Detail

Kerajinan

Halaman detail kerajinan adalah halaman yang akan muncul ketika pelanggan menekan salah satu item pada list kerajinan. Halaman ini berisikan carouselView galeri kerajinan, detail info kerajinan, panel untuk melakukan pemesanan kerajinan dan panel ulasan pengguna tentang produk. Untuk melakukan pemesanan costumer cukup menginput jumlah kerajinan yang ingin dibeli.

3. Halaman Daftar Pemesanan

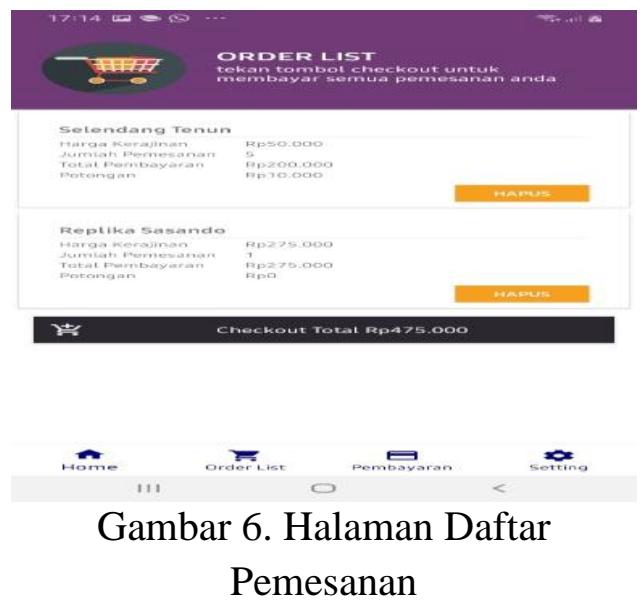

Halaman list pemesanan akan muncul ketika pelanggan melakukan pemesanan kerajinan atau menekan tombol list pemesanan pada navigasi. Halaman ini berisi list pemesanan yang memiliki tombol hapus dan sebuah tombol checkout yang memiliki informasi total pembelian kerajinan.

4. Halaman Pembayaran

Halaman ini akan muncul ketika pelanggan menekan salah satu item dalam list pembayaran yang memiliki status "Menunggu Pembayaran". Halaman ini berisi informasi mengenai daftar kerajinna yang dibeli, informasi kurir, detail info pembayaran, informasi bank, sebuah panel untuk mengupload bukti transaksi dan sebuah tombol submit untuk mengirim informasi pembelian kepada admin. 
DOI: https://doi.org/10.33330/jurteksi.v7i2.643

Available online at http://jurnal.stmikroyal.ac.id/index.php/jurteksi
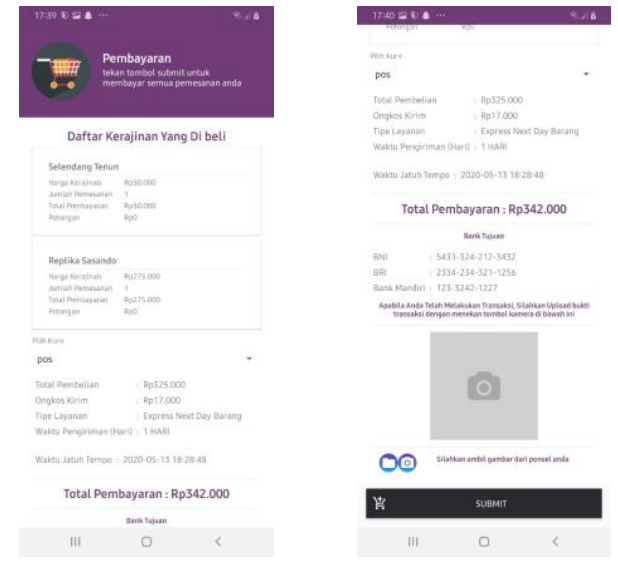

Gambar 7. Halaman Pembayaran

5. Halaman Login Admin

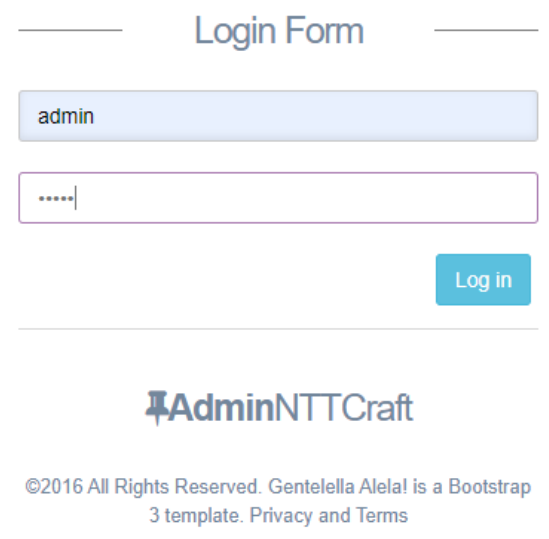

Gambar 8. Halaman Login Admin

Halaman login adalah halaman pertama yang muncul ketika mengakses website. Halaman ini berfungsi sebagai tempat untuk admin melakukan otentikasi sebelum menggunakan sistem. Otentikasi yang dilakukan adalah dengan menggunakan username dan password.
6. Halaman Dashboard

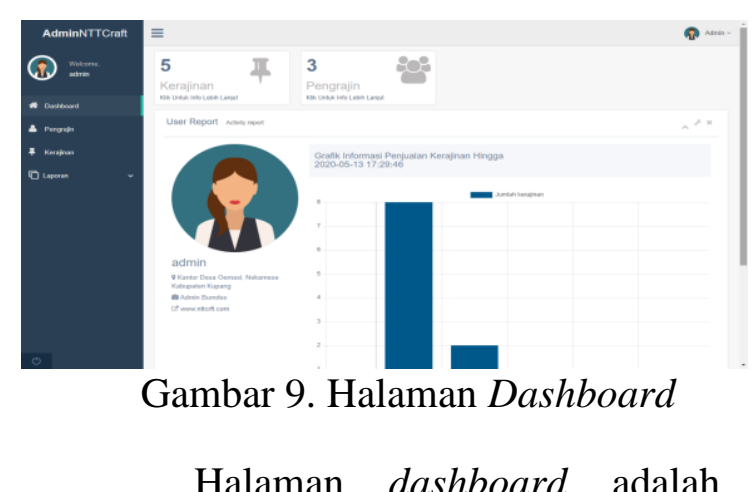

halaman yang muncul setelah admin melakukan otentikasi. Halaman ini memiliki sidebar yang berisikan menu-menu seperti dashboard, pengrajin, kerajinan dan laporan. Selanjutnya halaman ini memiliki top navigasi yang berisikan menu untuk logout, lalu footer yang berisikan informasi template website dan developer. Dan juga halaman ini memiliki konten yang berisikan informasi tentang jumlah kerajinan, jumlah pengrajin, informasi operator dan grafik penjualan kerajinan.

7. Laporan Penjualan Kerajinan

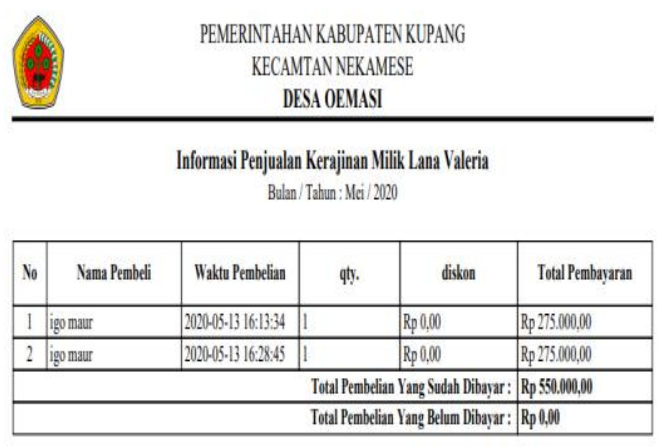

Gambar 10. Laporan Penjualan Kerajinan 
DOI: https://doi.org/10.33330/jurteksi.v7i2.643

Available online at http://jurnal.stmikroyal.ac.id/index.php/jurteksi

\section{SIMPULAN}

Aplikasi yang direkayasa dapat dijadikan sebagai media promosi kerajinan dengan menampilkan data-data kerajinan dan galeri kerajinan. informasi kerajinan pun dapat diulas dan dibahas oleh pengguna aplikasi, aplikasi yang direkayasa dapat mengupdate stok kerajinan ketika dipesan dan ketika pemesanan menjadi expired, aplikasi yang direkayasa dapat mencatat histori penjualan kerajinan setiap waktu dan merepresentasikannya dalam bentuk grafik dan juga dapat dicetak dalam bentuk .pdf, aplikasi yang direkayasa dapat digunakan oleh pihak desa untuk memantau dan mengontrol penjualan kerajinan yang dihasilkan oleh masayarakat desa Oemasi. Dengan demikian aplikasi yang direkayasa dapat dijadikan sebagai alternatif untuk melakukan penjualan kerajinan khas masyarakat NTT, khususnya masayarakat di desa Oemasi yang telah dibuat oleh para pengrajin. Masalah - masalah seperti metode penjualan kerajinan secara konvensional dan via media sosial dapat diselesaikan dengan aplikasi yang telah direkayasa.

\section{DAFTAR PUSTAKA}

[1] W. Jony, Internet Marketing for Beginners. 2010.

[2] Vermaat, "Discovering Computers: Menjelajah Dunia Komputer Fundamental Edisi 3," 2007.

[3] M. Suyanto, "Top, Strategi Periklanan pada E-Commerce Perusahaan Dunia," PT. Elex Media Komputindo Kelompok Gramedia, Jakarta, 2003, doi: 10.1371/journal.pmed.1002471.

[4] Katadata.co.id, "73\% Perangkat
Mobile Global Menggunakan Android," Katadata.co.id, p. 1, 2017, [Online]. Available: https://databoks.katadata.co.id/data publish/2017/10/09/73-perangkatmobile-global-menggunakanandroid.

[5] E. P. Papadopoulos, M. Diamantaris, P. Papadopoulos, T. Petsas, S. Ioannidis, and E. P. Markatos, "The long-standing privacy debate: Mobile websites Vs mobile apps," 26th Int. World Wide Web Conf. WWW 2017, pp. 153-162, 2017, doi: 10.1145/3038912.3052691.

[6] S. H. R. Wong, "Which platform do our users prefer: Website or mobile app?," Ref. Serv. Rev., vol. 40, no. 1, pp. 103-115, 2012, doi: 10.1108/00907321211203667.

[7] O. Irnawati et al., "Penerapan model waterfall dalam analisis perancangan sistem informasi inventarisasi berbasis web," vol. 6, no. 2, pp. 109-116, 2020, [Online]. Available: https://jurnal.stmikroyal.ac.id/inde x.php/jurteksi/article/view/406.

[8] N. Susanti, "Perancangan EMarketing Umkm Kerajinan Tas," Simetris J. Tek. Mesin, Elektro dan Ilmu Komput., vol. 9, no. 1, pp. 717-722, 2018, doi: 10.24176/simet.v9i1.2042.

[9] E. Haerulah and S. Ismiyatih, "Aplikasi E-Commerce Penjualan Souvenir Pernikahan Pada Toko ' Xyz ," J. Prosisko, vol. 4, no. 1, pp. 43-47, 2017, [Online]. Available: http://ejurnal.lppmunsera.org/index.php/P ROSISKO/article/download/146/2 08 .

[10] S. N. Marijan, "PERANCANGAN SISTEM INFORMASI 
DOI: https://doi.org/10.33330/jurteksi.v7i2.643

Available online at http://jurnal.stmikroyal.ac.id/index.php/jurteksi

\begin{abstract}
AKADEMIK BERBASIS WEB PADA Program Studi Sistem Informasi , STMIK Nusa Mandiri Jakarta JURTEKSI (Jurnal Teknol. dan Sist. Informasi), vol. VI, no. 1, pp. 71-78, 2019.
\end{abstract}

[11] Pressman, "Library Binus," Softw. Eng., 2015.

[12] Majed.rifat, "Chapter 6 . DataFlow Diagrams Introduction to data-flow diagrams What are dataflow diagrams ?," pp. 1-37. 